\title{
Undifferentiated Spindle Cell Sarcoma
}

National Cancer Institute

\section{Source}

National Cancer Institute. Undifferentiated Spindle Cell Sarcoma. NCI Thesaurus. Code C121797.

An undifferentiated soft tissue sarcoma characterized by the presence of a malignant spindle cell infiltrate with amphophilic or palely eosinophilic cytoplasm. 